\title{
Ali el-Kârî’nin Rafizî Safavîlere İlişkin Osmanlı Merkez Ulemasına Reddiyesi
}

\author{
Hasan Hüseyin Güneş*
}

Öz

XVI. yüzyılın önemli düşünürlerinden Ebü'l-Hasen Nûruddin Ali b. Sultan Muhammed el-Kârî el-Herevî (ö. 1014/1605), Osmanlı ve Safavî devletlerinin mücadelelerinin yoğun olduğu bir dönemde yaşamış bir düşünürdür. Safavî siyasetinin neticesinde Osmanlı topraklarına iltica etmiş Hanefî ulemadan olmakla birlikte, Osmanlı merkez ulemasının çizmiş olduğu siyasal mezhep düsturlarının dışına çıkmıştı. Şiilerin tekfir edilmesi, öldürülmesi gibi fetvaları incelemiş ve fetvalardaki gerekçelerin İslam ahkâmı ile bağdaşmadığını, fetvaların İslam hukukuna uygun olmadığını belirtmiştir. $\mathrm{O}$, söz konusu görüşlerini hem tertip ettiği ilim meclislerinde hem de eserlerinde ele almıştır. Bu çalışmanın amacı, Ali el-Kârî’nin zikredilen görüşlerini açıkladığı iki eserini incelemektir. Bunların ilki Şeтmu'l-Avârız fì Zemmi'r-Revâfiz adlı eseridir. Diğeri ise bu eserin özeti mahiyetindeki Sülâletü'r-Risâle adlı yazma eserdir. Bu çalışmada Ali el-Kârî’nin bu eseri yazma sebebi ve bu iki eserin benzer ve farklı yönleri üzerinde durulacak ve içerik analizi yapılacaktır. Çalışmanın bir diğer amacı, Osmanlı ulemasının Şiî Safavî devleti ile mücadele için öne sürdüğ̈ gerekçelerin yaygın olmasına rağmen tüm Sünni Hanefi ulema tarafından kabul edilmediğini göstermektedir.

Anahtar Kelimeler: Ali el-Kârî, Osmanlı Uleması, Safavî, Rafizî, Yazma Eser

Doç. Dr., Bartın Üniversitesi, Tarih bölümü, hasan.h.gunes@gmail.com, ORCID: 0000-0002-1797-3605. 


\title{
Ali al-Qari's Objections to The Ottoman Central Scholars About Heretics Safavids
}

\author{
Hasan Hüseyin Güneş*
}

\begin{abstract}
XVI. Ebu'l-Hasen Nuruddin Ali b. Sultan Muhammad al-Qari al-Herawi (d. 1014/1605) was a thinker who lived in a period when the struggles of the Ottoman and Safavid states were intense. As a result of Safavid politics, he was a Hanafi scholar who defected to Ottoman lands. However, he had gone beyond the political sectarian principles of the Ottoman central ulama. He examined the fatwas such as the repudiation and killing of the Shiites and stated that the reasons in the fatwas were incompatible with the Islamic court and that the fatwas were not in accordance with Islamic law. He discussed these views both in his scientific assemblies and in his works. The aim of this study is to examine two of Ali alQari's books in which he explained his views. The first of these is Şemmu'l-Avâriz fî̀ Zemmi'r-Revâfiz and the other is Salâletü'r-Risâle, the summary of this book. In this study, we will focus on the reason of Ali al-Qari's writing of this book and examine on the similar and different aspects of these two books and we will make a content analysis. Another aim of this study is to express that although the reasons that the Ottoman ulama give for the struggle against the Shiite Safavid state are fairly common, they are not accepted by all Sunni Hanafi scholars.
\end{abstract}

Keywords: Ali al-Qari, Ottoman Ulema, Safavids, Rafidi, Manuscript

Assoc. Prof. Dr., Bartın University, Department of History, hasan.h.gunes@gmail. com, ORCID: 0000-0002-1797-3605. 


\section{Giriş}

Retoriğin, başkalarının söz ve düşüncelerini eleştirmeyi ve reddetmeyi amaçladığ 1 söylenir. İslam tarihi, dinlerin ve mezheplerin çeşitliliği nedeniyle söz konusu retoriği içeren eserlerle doludur. Bunların birçoğu sadece belirli bir dinin veya mezhebin meşruiyetini temsil etme, muhaliflerine ve mensuplarına söz konusu meşruiyeti kanıtlamaya çalışmaktadır. İslam tarihi boyunca bu zeminde öne sürülen karş1lıklı argümanlar, özellikle Şiiler ve Sünniler arasında geniş bir literatür oluşturmuş̧tur.

Meselenin ilgi çekici bir diğer yanı, Şiilerin kısa Büveyhî egemenliği yanı sıra Safavîler'e dek siyasal/politik iktidardan ve onun güç ve araçlarından uzak olmalarına rağmen, entelektüel ve ideolojik çekişme sahnesinden ayrılmamış olmalarıdır. Bunu kimi zaman meşru kabul etmedikleri iktidara ayaklanmak suretiyle gerçekleştirirken, çoğu zaman fikri cereyanlar içerisinde düşünsel temellerini güçlendirerek yapmışlardır. Bu minvalde teolojik konulardaki Şii literatür, rakipleriyle boy ölçüşecek düzeye gelmiştir. Ancak iktidar alanından uzak olmaları dolayısıyla bu yazında, kendilerine mukabil üretilen retoriğe karşı bir söylem oluşturmuş; üstelik bu savunu söylemi Şii literatürünün yaygınlaşıp rakiplerine göre zenginleşmesine olanak sağlamıştır. Zira Sünniler iktidar haklarından kaynaklanan güçlerini daha çok tabiri yerindeyse "saldırı" amaçlı kullanmışlardır. Dolayısıyla savunmaya çok az ihtiyaç duydular ve Şiiliğe ve ontolojisine daha şüpheci yaklaştılar.

Ancak meşruiyetlerini koruma adına Şiilerin, iktidarın üretmek istediği söyleme cevap vermek ve fikri argümanlarını savunmaktan başka seçenekleri bulunmamaktaydı. Zira siyasalarının temellendiği teolojik statülerini korumak ancak bu şekilde mümkün olabilmiştir. Bu nedenle, kendilerine ilişkin üretilen ve söyleme sokulan sorunsallara veya suçlamalara reddiyeler diyebileceğimiz cevap mahiyetinde eserler yazmışlardır.

Şîa mezhebine mensup olmayan birçok âlim, Şii tarihine ve inançlarına karşı kitaplar yazmıştır. Ebû Sehl Bişr b. Mutemir Hilaî Bağdaî’nin erReddu Ale'r-Râfiza; Bişr b. Giyâs b. Ebî Kerîme el-Merîsî el-Adevî'nin er-Reddu ale'l-İmâme; Ebû Bekir Abdurrahman b. Keysan Esamm erReddu Ale'r-Râfiza; Ebû Amr Dirâr b. Amr el-Gatafânî er-Reddu ale'rRâfizeti ve'l-Haşeviyye; Cahız Amr b. Bahr Basrî’nin el-İmâmetu alâ Mezhebi'ş-Ş̂̀'a; İbni Bakıllânî Muhammed b. Tayyib b. Muhammed 
Basrî'nin, er-Reddu ale'r-Râfiza; Ebu'l-Kasım Hibetullah b. Abdullah Kaftî'nin er-Reddu ale'r-Râfiza; İbni Teymiyye'nin er-Reddu ale'r-Râfiza ve'l-Mu'tezile ve'l-Havâric ve'l-Cehmiyye; İbni Akuli Muhammed b. Muhammed b. Abdullah Vasitî Bağdadî Şafî̀'nin er-Reddu ale'r-Râfiza; Abdullah Tazî Merâkeşî’nin el-Munâzara ve'l-Mu'âraza fî Reddi'r-Râfiza; Nureddin Ali b. Sultan Muhammed Kârî Herevî'nin Sülâletü'r-Risâle fì Zemmi'r-Revâfiz min Ehli'd-Delâle; Ali b. Ahmed Heytî'nin es-Seyfu'lBâtir li-Rikâbi'ş-Ş̂̀'ati ve'r-Revâfizati'l-Kevâfir ve; İmam Rabbanî olarak bilinen Amed b. Abdülahad Serhendî Farukî'nin er-Reddu'ş-Şı̀’a isimli bir eserleri örnek olarak verilebilir. Bu makalenin konusu, yukarıda örnek olarak isimleri zikredilen eserler içerisinden Nureddin Ali b. Sultân Muhammed el-Kârî Herevî'nin Sülâletü'r-Risâle fì Zemmi'r-Revâfiz min Ehli'dDelâle ve onun mufassalı addedilebilecek Şemmu'l-Avârı fì Zemmi'rRevâfiz adlı eserleridir.

XVI. yüzyılın önemli düşünürlerinden Ebü'l-Hasen Nûreddin Ali b. Sultan Muhammed el-Kârî el-Herevî (ö. 1014/1605), ilk tahsilini doğduğu şehir Herat'ta yaptıktan sonra Mekke'ye gitmiş ve oraya yerleşmiş, bu şehrin muhtelif ulemasından ders almıştır. Fıkıh, hadis, kıraat, tefsir, akaid, kelâm, tasavvuf, tarih, dil ve edebiyat sahalarında, yaşadığı dönemin önde gelen âlimleri arasında görülmüştür. Kıraat ilmine olan vukufundan dolayı el-Kârî veya genel olarak Molla Ali el-Kârî şeklinde adlandırılmıştır. ${ }^{2}$ Ali el-Kârî, Safavî devletinin gerçekleştirdiği siyasetten hiç hoşnut olmamıştır. İçinde bu devlete karşı büyük bir kin beslemiştir. Hiç şüphesiz Tebriz ve Harat'ta Safavî hâkimiyetinin tesis edilmesi bunda büyük önem arz etmiştir. Bölgenin önde gelen Şah İsmail'in Herat'a girişinden sonra, Ehli Sünnet âlimlerinden Herat Câmi-i Kebîr hatibi Şeyh Muinuddin el-Îcî ve Taftazanî’nin torununun öldürülmesini bir eserinde anlatmaktadır. ${ }^{3}$ Anlaş1ldığ kadarıyla Ali el-Kârî’nin Şiî Safavî devletine karşı retorik geliştirmesine neden olacak içtimaî ve psikolojik nedenleri bulunmaktaydı.

Ali el-Kârî kendi döneminde gözlemlediği hurafelere karşı durup bunları eserlerinde ele almıştır. Bunun yanı sıra Ehl-i Sünnet geleneğinde değer verilen bazı isimleri açıkça tenkit etmesi nedeniyle kimi çevrelerce sevil-

Ali b. Sultan el-Kârî, Şemmu'l-Avârız fì Zemmi'r-Revâfiz, (Kahire: Merkezu Furkan li-Dirasat İslamiyye), 1425/2004.

Ahmet Özel, “Ali el-Kari”, (İstanbul: TDVIA, 1989), 2: 403.

el-Kârî, Şemmu'l-Avârız fì Zemmi’r-Revâfiz. 
mediğini söylemek mümkündür. Hanefî mezhebine bağl1lı̆̆ıla bilinen Ali el-Kârî, tasavvufa ilgi duymuştur. Ancak kelâm ve tasavvuf mevzularında aşırı temayüllere karşı durmuş ve bunları açıkça eleştirmiştir. Bu sebeplerle sevilmediği çevrelerde eserlerinin okunmaması yolunda görüşler bildirilmiştir. Söz konusu engellemeler eserlerinin yayılıp okunmasına engel teşkil etmemiştir. Kimileri onu 1000. yılın başlarındaki mücedditlerden saymış, el-Kârî de "tahdîs-i ni'met" kabilinden kimi zaman bunu dile getirmekten imtina etmemiştir. ${ }^{4}$

İtikat konularında İbn Teymiyye (ö. 622/1225) ve İbn Kayyım'ın (ö. 751/1350) görüşlerini takip etmiş, buna göre vahdet-i vücud düşüncesine karşı çıkmakla kalmamış, bu görüşü nedeniyle İbnü'l- Arabî’yi tekfîr ettiği belirtilmiştir. Selefî âlimlerin iddialarını savunması nedeniyle bazı ulema ve mutasavvıfların ona karşı mesafeli durmalarına, eserlerinin okunmamas1 için fetvâlar vermelerine neden olmuştur. ${ }^{5}$ Bunun yanında el-Kârî'nin İbn Teymiyye'nin kimi görüşlerinin yanlış anlaşıldığının altını çizmiş olması önemlidir. ${ }^{6}$

Ali el-Kârî'nin kelam ve hadis ilimlerinde eserler yazdığını söylemek mümkündür. Tanınmıș eserleri arasında el-Esrâru'l-Merfû'a fì Ahbâri'lMevzû'a, Mirkâtü'l-Mefâtîh Şerhu Mişkâti'l-Mesâbîh, Şerhu'l-Müsnedi'lİmâm Ebû Hanîfe, Şerhu'ş-Şifâ li Kâdı İyâz, Şerhu'l-Fıkhi'l-Ekber'i bulunmaktadır. Ayrıca fakihliğini ortaya koyduğu Fethu Bâbi İnâye bi Şerhi'nNukâye'yi unutmamak gerekmektedir. Envâru'l-Kur'ân ve Esrâru'lFurkân adlı eseri ise onun tefsir çalışmasıdır. ${ }^{7}$

\section{Ali el-Kârî’nin Meseleye Metodolojik Yaklaşımı}

Safavîlerin tarih sahnesine bir Şiî devlet olarak konumlanışı, Sünnî ve Şiî ulema arasında Şiilik bağlamında süregelen tartışmaların yeniden gün yü-

\footnotetext{
Özel, “Ali el-Kari”, 403.
}

Ahmet Karataş, “Aliyyul-Kārinin el-Mulemma' Şerhu'n-Na'ti'l-Murassa' Adlı Arapça Risalesinin Tercüme ve Şerhi”, Tasavvuf İlmi ve Akademik Araştırma Dergisi 17, no. 37, (2016): 147.

6 Ali b. Sultan el-Kârî, Hâmişi Nesîmu'r-Riyâz fì Şerhi'ş-Şifâu'l-Kâdî Iyâz ve biHâmişihî Şerhu'ş-Şifâ, (Beyrut: Darulkutubul Arabi), 1327.

7 Ali Can, “Aliyyü'l-Kârî'nin Envâru'l-Kur'ân ve Esrâru'l-Furkân Adlı Tefsirinde Besmele Yorumu”, Dicle Üniversitesi İlahiyat Fakültesi Dergisi 14, no. 2 (2012): 44. 
züne çıkmasına ve ateşli tartışmalar etrafında geçen saldırı/müdafaa literatürünün genişlemesine zemin oluşturmuştur. ${ }^{8} \mathrm{Bu}$ eserlerden bazısı sadece saldırı veya sadece müdafaa için yazılmışken, bir kısmı her iki hususiyete sahip olabilmekteydi. Bu çerçevede Ali el-Kârî'nin Şia'ya reddiye sergileyen eserlerinden biri Şemmu'l-Avârız fì Zemmi'r-Revâfiz'dır. el-Kârî tarafından bu eserinde çözümlenmek istenen ilk mesele Hz. Peygamberin sahabeleriyle ilgilidir. Sahabeye sövmenin mübah olduğunu düşünen kişinin icmâ ile fasık ve bid'at ehli olduğunu belirten el-Kârî, Şia'nın bu kötü eylemi gerçekleştirdiğini ifade etmiştir. Hatta Şia'nın böyle bir amelin sevabına dair görüş bildirdiğini kaydetmiştir. Bunun yanında, sahabelerden birinin veya Ehl-i Sünnet'in küfrüne hükmeden birinin icmâ ile kâfir olduğuna değinerek, açık açık dile getirmemekle birlikte, burada yine Şia'nın bu görüşe sahip olduğuna işaret etmiştir. Sahabeye küfreden kişinin fasık, onlardan birinin küfrüne hükmedenin kâfir olduğu icmâ ile sabit olunca, el-Kârî bunun hukukî müeyyidelerine değinmiştir. ${ }^{9}$

Ali el-Kârî’ye göre, küfrün sübutu tahakkuk ettiğinde müeyyidesinin de tahakkuk etmesi mümkün hale gelmektedir. Bu bağlamda Şia'nın bidat ehli olduğuna hükmetmekle birlikte, dönemin Osmanlı merkez ulemasının yaygın olan görüşüne, başka bir ifadeyle, Şia'nın mürtet kâfirler olduklar1na dolayısıyla öldürülmeleri gerektiğine/öldürülebileceklerine dair görüşe katılmamaktadır. Bilakis Şemmu'l-Avârız fì Zemmi'r-Revâfiz'1 yazma sebebi sahabeye küfretmenin (sebb) küfrü meydana getiren bir mevzu olmadığıdır. Ona göre söz konusu eylem akait bağlamında değil, fikıh çerçevesinde ele alınması gereken bir konudur. Buradan hareketle el-Kârî, akidevî meselelerin kat'î delillere ihtiyaç duyduğunu ve bunlarla açılanabileceğini, fer'î sayılan fikhî meselelerin ise zannî delillerle izah edilebileceğine değinmiş, Şiîlerin akidevî gerekçelerle öldürülmelerinin yanlış olduğunu eserin girişinde belirtmiştir. el-Kârî, bu görüşlerini açıç̧a kendi tertip ettiği ilim meclislerinde dile getirmesinin tepkilere yol açtığını ve bu nedenle ulemadan bazılarının bu meclislerden uzak kalmayı tercih ettiğini açıkça ifade etmiştir. ${ }^{10}$ Özetlemek gerekirse, Osmanlı merkez ulemasının yaygın

8 Bir örnek için bkz., Adem Arıkan, "Osmanlı Kadısı/Müderrisi Maruf b. Ahmed'in İmâmiye Şîasına Eleştirileri”, Marife 8, no.3, (Kış 2008): 331-348.

9 el-Kârî, Şemmu 'l-Avârız fì Zemmi'r-Revâfiz, 28.

10 el-Kârî, Şemmu'l-Avârız fí Zemmi'r-Revâfiz, 21-24. 
tabiriyle Rafizîler ${ }^{11}$ tabirini kullanmaktan imtina etmeyen el-Kârî, onların öldürülme gerekçelerinin iki kategoride değerlendirilmesi gerektiğini belirtmiştir. Buna göre mesele akidevî gerekçelere veya hukukî dayanaklara isnat edilerek değerlendirilebilir. Ancak el-Kârî, akidevî gerekçelerin Rafizîlerin öldürülmesi için öne sürülemeyeceğini savunmuştur.

$\mathrm{Bu}$ çerçevede el-Kârî, icma görüşünün sahabeye sebbedenin fasık, onlardan birinin kâfir olduğunu savunanların kâfir statüsünde sayılacağını belirtmiştir. el-Kârî, Şia'nın fesat ve yanlış itikatlarından kaynaklanan inatlarının defi için, "ulemâmıza göre siyaset edilip öldürülmeleri gerekmektedir" görüşünü hatırlatmaktadır. Zikredilen görüşü Hz. Peygamberin ashabından Abdullah b. Mesud'dan nakledilen şu hadise dayandırır: "Müslüman birinin kanı şu üç durum haricinde dökülemez: (1)ihtiyar (evli) zinakar, (11)irtidat eden ve (111)cemaatinde ayrılık çıkaran."12 el-Kârî, bu hadisin Buharî, Müslim, Ebû Davud, Tirmizî ve Nesâ̂’nin hadis derlemelerinde zikredildiğini hatırlatarak hadisin muteber kabul edilen hadis kaynaklarında yer aldığına değinmiştir. Yukarıdaki görüşleri aktaran el-Kârî, icmaın başka bir yorumuna yer vererek, bir Rafizî tek başına olur, bidatini ve küfrünü aşikâr etmezse, bir başka ifadeyle, dinin değiştirildiği kısımlarını toplum içerisinde dillendirmezse öldürülmesinin yasak olduğunu hatırlatmıştır. Dolayısıyla el-Kârî, Rafizîlerin öldürülmesinin bağy ehli olmaları durumunda mümkün olduğuna hükmetmiştir. ${ }^{13}$

Rafızilerin doğruyu bulmaları için onlarla sosyal ilişkilere devam edilmesini savunan el- Kârî, icmaa göre Rafizî ve Haricî olan bağy ehliyle savaşmanın gerekliliğini, topluluk halinde hareket etmeyip münferit oldukları müddetçe onları öldürmenin caiz olmadığını belirtmiştir. Bu hüküm Şii’den aleni bir şekilde küfür özellikleri sadır olmadığı müddetçe meridir. "Benzer bir durum namaz kılmayan ve zekât vermeyenler için geçerlidir", der el-Kârî ve ekler, "biri namaz kılmadığından onunla savaşılmaz ancak

11 Rafızî tabiri sözlüklerde "terk eden, bırakan, ayrılan” anlamına gelmektedir. Çoğulu revâfiz olarak kullanılmaktadır. Terim olaraksa, İlk olarak Zeyd b. Ali'den ayrılan ilk İmâmîler'e, akabinde bütün Şî̂ firkaları ile Şiî unsurları taşıyan bir takım bâtınî gruplarına yakıştırılan isimdir. Ayrıntı için bkz. Mustafa Öz, "Rafıziler", (İstanbul TDVIA 2007), 34: 396-397. Bu terimin bizzat İmamiye Şiası tarafından kullanıldığına dair bkz., Etan Kohlberg, "İmâmiyye Şiası Geleneğinde "Râfizî" Terimi”, çev. Halil İbrahim Bulut, Kelam Araştırmaları 2, no. 2 (2004): 117-124.

12 Devlete isyan etme bağlamında.

13 el-Kârî, Şemmu'l-Avârız fí Zemmi'r-Revâfiz, 28-29. 
bir köy halkı ezan okumaz ve namaz eda etmezse veya bir topluluğun hepsi zekât vermekten imtina ederse onlarla savaşmak ve onları öldürmekte beis yoktur."14

\section{Sahabeye Sövmenin Küfrü Gerektirdiği Tezi}

el-Kârî, sahabelerinin küfürle itham edilmesi meselesi için ayrı bir başlık açmıştır. İlk olarak bu meselenin ele alınmasının nedeni, Rafızîlerin küfürle itham edilmesinde en önemli sebep olarak gösterilmesi, toplum ve siyaset arenasında öne çıkması olmuştur. el-Kârî, umumî olarak sahabenin ve özellikle Şeyhayn diye anılan birinci ve ikinci halifenin ardından sövmenin küfürle itham edilip edilemeyeceğini tartışmaya açmıştır. Usulde şer'î edillenin kitap, sünnet ve ümmetin icmaı olduğunu belirterek konuya giriş yapan el-Kârî, söz konusu tartışmada Kur'ân ve ümmet icmaının çerçevenin dışında kaldığını belirtmiş, dolayısıyla konuya ancak hadislerle açıklık kazandırılabileceğini savunmuştur. Mevzua ilişkin hadisler incelediğinde isnat açısından bu hadislerin âhâd hadisler kategorisine girdiğini tespit etmiştir. ${ }^{15}$ Tartışmaya konu hadislerin zannî delil teşkil ettiğini hatırlatan el-Kârî, fakihlerin eserlerinde sahabeye sövme hakkında bir irtidattan

14 el-Kârî, Şemmu'l-Avârız fì Zemmi'r-Revâfiz, 30-31.

15 “' 'Bir' anlamındaki Arapça vâhidin haber kelimesine muzaf kılınması (haberü'lvâhid) veya sıfat tamlaması şeklinde kullanılmasıyla (haberün vâhidün) ortaya çıkmış olup “bir kişinin diğer bir kişiden naklettiği haber” demektir. Vâhid kelimesinin çoğulu olan âhâdla beraber bulunduğunda ise (haberü'l-âhâd, ahbârü'l-âhâd) "birden fazla kişinin rivayet ettiği haber" anlamına gelir. Ancak bunlar, usul kitaplarında çoğunlukla birbirinin eş anlamlısı olarak kullanılmakla beraber hadisin âhâd vasfını taşımasının onun her zaman haber-i vâhid olduğunu göstermeyeceği de söylenmektedir. Bundan dolayı hadisçiler, usulcüler ve fakihler tevâtür derecesine ulaşmayan bir haberi "âhâd haber" kabul ettikleri için haberi nakleden râvi sayısının bir, iki, üç veya daha fazla olması arasında fark yoktur. Haber-i infirâd da denilen haber-i vâhid Hz. Peygamber'den rivayet edilen hadisler, sahâbe ve tâbiînden nakledilen haberler için kullanılmakla birlikte hadiste ve diğer İslâmî ilimlerde zikredildiğinde daha ziyade Resûl-i Ekrem'den rivayet edilen hadisler akla gelir. Hadis ilminde, haber-i vâhid için bu genel tarifin dışında özel olarak sahih ve hasen haberin tarifine denk tanım da yapılmaktadır. Buna göre haber-i vâhid, mütevâtir sünnetin dışında kalan ve Resûlullah'tan itibaren adalet ve zabt sıfatlarını taşıyan bir veya iki yahut tevâtür derecesine ulaşmayan sayıda sahâbenin, daha sonra tâbiînin ve tebeu't-tâbiînin rivayet ettiği, metninde şâz ve illet bulunmayan ve zann-1 gālib ile (râcih) sabit olan habere denir. Bir habere rivayet yollarının çoğalması sebebiyle "meşhur" denilse bile bu haber âhâd olmaktan çıkmaz." Ayrıntı için bkz. Mustafa Ertürk, "Haber-i Vâhid", (İstanbul TDVIA 1996), 14: 349. 
söz edilmediğine değinmiştir. ${ }^{16} \mathrm{Bu}$ açıklamalardan sonra avamın dilinde Şeyhayn'e sövmenin küfre sebep olduğuna dair yaygın görüşe odaklanmış, bu minvalde tedavülde olan rivayetlerin kesinlikle ilmî bir değerinin bulunmadığını açıkça ifade etmiştir. Aslında bu nevi rivayetleri kendisinin görmediğini belirtmekten kaçınmamıştır. el-Kârî, bu rivayetlerin mevcut olsalar bile zahiriyle hükmetmeye elverişli olmadıklarına hükmetmiş ve tıpk1 namaz k1lmayan ve zekat vermeyenlere dair rivayet edilen hadisler misali tevil edilmeleri gerektiğini söylemiştir. Tevil yapılmaması ve her konuda rivayetlerin zahiriyle hükmedilmesi durumunda şer'î kaidelerin korunamayacağını, sıhhatli istidlallerin yapılamayacağını hatırlatmış ve özellikle Müslümanların tekfiri ve öldürülmeleri konusunda hataya düşüleceğini kaydetmiştir. Konuya dikkat çekmek için bir müftüye bir kişinin küfre geçtiğine dair doksan dokuz, İslamiyet’te kaldığına dair bir delil getirildiğinde, müftünün doksan dokuz delile değil, kişinin Müslüman olduğunu gösteren bir delile uyması gerektiği şeklinde bir örnek vermiştir. Zira müftünün bir hayatı kurtararak yapacağı hata, o hayatı yok etme hatasından ehvendir. Şeyhayn hakkında sövmenin küfrü gerektirdiğine dair avam arasındaki yaygın kanaatin bazı fetva kitaplarında rastlanmasına da

16 "Ehl-i sünnet âlimlerinin haber-i vâhid konusundaki görüşlerini şöylece özetlemek mümkündür: Mâtürîdiyye'nin kuruluşuna öncülük eden Ebû Hanîfe, Kur'an'a aykırı bilgiler ve hükümler ihtiva eden âhâd haberlerin reddedilmesi gerektiğini söylemiştir. Zira Hz. Peygamber'in Kur'an'a ve akla aykırı bir beyanda bulunması imkânsızdır. Bu temel ilkeyi kabul etmek peygamberi tasdik etmenin bir gereğidir. Ayrıca Kur'an'a ve akla aykırı olan haber-i vâhidin reddedilmesi Resûl-i Ekrem'i yalanlamak anlamına gelmeyip ona bu isnadı yapan kişinin sözünün kabul edilmemesi demektir. Böyle bir davranış, Hz. Peygamber'i Kur'an'a muhalif davranmış gibi göstermekten tenzih etmek için de gereklidir. Ebû Hanîfe'nin itikadî görüşlerini sistemleştiren Ebû Mansûr el-Mâtürîdî, haber-i vâhidin Resûl-i Ekrem'den gelen gerçekleri mütevâtir gibi belgeleyemediğini söyledikten sonra râvilerin durumlarının incelenmesi, haberin açık naslarla karşılaştırılıp muhtevasının değerlendirilmesi gibi ilmî faaliyetlerin yürütülmesi neticesinde ortaya çıkacak kanaatle hareket edilebileceğini belirtmiş, fakat bütün bunlara rağmen bu tür haberlerin gerçeği tam yansıtamayacağının ilke olarak benimsenmesini istemiştir (Kitâbü't-Tevhî̀, s. 9). Ebü'l-Muîn en-Nesefî ise kabir azab1 gibi âhiret hallerine dair âhâd haberlerin yaygınlık kazandığı için istidlâlî ilim ifade ettiğini kabul etmiştir. Son dönem kelâm âlimlerinden İzmirli İsmail Hakkı haber-i vâhidi, ilk üç asırda güvenilir fakat tevâtür derecesinin altındaki râviler tarafından nakledildiği halde daha sonraki asırlarda yaygınlık kazanan hadisler anlamında kullanmış ve bunlardan sahih kabul edilenlerin sadece zannî bilgi ifade ettiğinden akaid konularını kanıtlamak için kesin bir delil teşkil edemeyeceğini söylemiştir (Yeni İlm-i Kelâm, I, 30). Ancak aynı dönemde yaşayan Elmalılı Muhammed Hamdi gibi âlimler âhâd hadisleri akaid konularında da kesin delil olarak kullanmışlardır. " Ayrıntı için bkz., Yusuf Şevki Yavuz, "Haber-i Vâhid/Kelam", DİA, (İstanbul TDVIA 1996), 14: 353 . 
değinen el-Kârî, tahkik ehli olmayanların meçhul kişilerden yaptıkları ve onlara dayandırdıkları fetvaların doğru olmadığının altını çizmiştir. ${ }^{17}$

\subsection{Hanefî Mezhebinde Sahabeye Sövmenin Hükmü ve Bu Konudaki Rivayetlere el-Kârî’nin Bakışı}

el-Kârî, Ebû Hanife'nin ve Hanefî mezhebi ulemasının görüşünün yukarıda açıklandığ1 yönde olduğunu belirtmiş ve bunun haricinde fikir ileri sürenler olduğunu, onlar gibi kendinin de görüş bildirebileceğini, buna hakk1 olduğunu ifade etmiştir. Mevzuya bahis görüşlerin ne zannî ne de kat'î olduğunu, kitap ve sünnetten alınmadığını, Ebû Hanife'nin Fıkhu'lEkber'indeki görüşlerinin yanı sıra İmam Malik, Ahmed b. Hanbel, İmam Şafî̂ ve mütekellimlerin 'kıble ehli tekfir edilemez' görüşleriyle çeliştiğini açıkça serdetmiştir. ${ }^{18}$

Daha sonra bu tezini delillendirmek için ulemanın önde gelen kişilerin görüşlerini ve bir takım hadisleri nakletmiştir. Buna göre, Allame Teftazanî Şerhu'l-Akâid ${ }^{19}$ adlı eserinde sahabeye sövmenin küfür değil bid'at ve fisk olduğunu; Ebû Şekûr es-Salimî ise Temhî ${ }^{20}{ }^{0}$ isimli eserinde sahabeye sövmenin küfür olmadığını ifade etmiştir. Ayrıca Hz. Peygamberden nakledilen bir hadiste peygamberlere sövmenin katli gerektirirken, sahabeye sövmenin değnek cezasını icap ettirdiği; bir başka hadisteyse ashaba sövenin Allah'ın, meleklerin ve insanların lanetine uğrayacağı nakledilmiştir. ${ }^{21}$

el-Kârî tam da burada Şeyhayn (Ebu Bekir ve Ömer) ve Hasaneyn (Hasan ve Hüseyin) ve dahi diğer sahabeleri teşmil ederek, bunlardan herhangi birine sövmenin küfre girme sebebi sayılamayacağını ifade etmiştir. Yaptığı açıklamalar ve getirdiği delillerden sonra bundan başka bir görüşü savunanın cahil olduğunu, akidesini düzeltmesi, taassubu bırakması gerektiğini belirtmiştir. el-Kârî, öne sürdügü bu tezi çürütmek isteyenleri burhan meydanına davet etmiş ve her asırda bir müceddidin gönderileceğini müjde-

el-Kârî, Şemmu'l-Avârız fí Zemmi'r-Revâfiz, 33-34.

el-Kârî, Şemmu'l-Avâriz fí Zemmi'r-Revâfiz, 34.

Sadeddin Mesud b. Ömer et-Teftazanî, Şerhu'l-Akâidi'n-Nesefiyye, (Beyrut: Daru İhyaut Turasil Arabi, Tahkik: Ali Kemal), 1436/2014.

20 Ebû Şekûr es-Salimî, et-Temhîd fî Beyâni't-Tevhîd, (İstanbul: Diyanet Vakfi yay., Tahkik: Ömer Türkmen), 2017.

21 el-Kârî, Şemmu'l-Avârı fí Zemmi'r-Revâfiz, 35. 
leyen hadisi naklederek zımnen kendini işaret etmiştir. Akabinde Allah'a yemin ederek kitap ve sünnete vukufiyette kendinden daha âlim birini tan1mış olsaydı her türlü zorluğa katlanıp ona uyacağını belirtmiş, ancak böyle birinin olmadığını ifade etmekten de kaçınmamıştır. ${ }^{22}$

O halde sahabîlere sövmenin küfür sayıldığı; Ebû Bekir, Ömer ve diğer sahabeleri sevmenin imandan ve onlara buğzetmenin küfür olduğunu belirten mevcut rivayetlerin durumu nedir? el-Kârî bu soruya te'vil kapısını aralayarak cevap vermiştir. Burada küfürden kastın küfrân-1 nimet olduğunu, katli gerektiren hâl anlamında bir küfür olmadığını savunmuştur. $\mathrm{Bu}$ eylemlerin faillerinin uğrayacakları kötü sonu hatırlatmak açısından, hadislerde küfür ve benzeri ifadelerin yer aldığına değinen el-Kârî, başka hadislerle bunları açıklamaya çalışmıştır. Nitekim bu nevi hadislerin bir kısmında Müslüman birine sövmenin küfür değil ancak fasıklık sayılabileceğini belirterek, konuya ilişkin hadislerin tevil edilmeden zahiriyle değerlendirilmesini taassup olarak değerlendirmiştir. ${ }^{23}$

Meseleyi taassup mecrasına getiren el-Kârî, eserinde içtimaî ve tarihsel bir açıklamaya da yer vermiş̧ir. Kendi tecrübelerinden bazılarını paylaşan elKârî, Safavîlerin Tebriz havalisini ele geçirişini ve kendi hocalarının içerisinde olduğu bazı şahısların öldürülüşünü aktardıktan sonra, Safavîlerin bu eğilimine sebep olanların Özbekler olduğuna dikkat çekmiştir. Anlatısında, Özbekler'in abdest alırken kollarını dirseklerden yukardan aşağı doğru yıkayan, ayaklarını yıkamak yerine mesheden veya secde ettiği yere taş koyanları gördüklerinde bunların Şiî olduğuna hükmedip öldürdüğüne; buna mukabil karşı tarafın, abdest alırken boynunu meshedip kulaklarını y1kayanları katlettiğine; Özbeklerin ellerini namaz esnasında bağlamayıp iki yana salanları öldürdüğüne, buna karşılık diğerlerinin namaz kılarken ellerini bağlayanları katlettiğine; Özbeklerin sahabeye söveni öldürdüğ̈̈ne, diğerlerinin insanlara zorla sahabîlere kötü söz söyletmeye çalıştığına ve buna uymayanları katlettiğine yer vermiştir. ${ }^{24}$

el-Kârî, yukarıda kısaca örneklendirdiği hadiselerin tarihsel arka planını çizmeye başlamış ve Emevîlerin sahabeye sövme adetinin ilk uygulay1c1ları olduğunu belirtmiştir. Nitekim bu hanedan hükmünün cari olduğu

\footnotetext{
22 el-Kârî, Şemmu'l-Avârız fí Zemmi'r-Revâfiz, 37-38.

23 el-Kârî, Şemmu'l-Avârız fí Zemmi'r-Revâfiz, 38-40.

24 el-Kârî, Şemmu'l-Avârız fí Zemmi'r-Revâfiz, 42-45.
} 
dönemde Ali ve taraftarlarına minberlerden lanetler okutmaktaydı. Bu uygulama Emevîlerden Ömer b. Abdülaziz tarafından kaldırılmış ve yerine "Muhakkak Allah, adaleti, iyiliği ve akrabalara yardım etmeyi emreder; fahiş şeyleri, iğrenç şeyleri ve zulmü yasaklar. Size öğüt veriyor ki hatırlayasınız" ${ }^{25}$ ayetinin okunmasını sağlamıştır. ${ }^{26}$

Açıklanan tüm sövme uygulamaları ve onun neden olduğu fillerin her biri el-Kârî'ye göre kitap ve sünnete hakkıyla uyulmaması sebebiyle gerçekleşmiştir. Sahabeye sövmenin en büyük günahlar arasında yer aldığını kabul eden müellif, icmaa göre birini öldürmenin hakeza büyük günahlardan olduğunu hatırlatmıştır. ${ }^{27} \mathrm{Bu}$ çerçevede Safavî devleti ile savaşmanın hükmünün fikhî mevzuatta nasıl konumlandırılacağ1 sorusu gündeme gelmektedir. el-Kârî, Safavîlerle savaş hususunda hiç tereddüt etmeden Horasan'ın daru'l-harb olmadığını belirterek net bir ifadeyle görüşünü dile getirmiştir. Üstelik Horasan sakinlerinin çoğunun Ehl-i Sünnet’ten olduğunu hatırlatmıştır. Şehirde Hanefîlerin Şafîllerden çok olduğunu, Şiîlerinse azınlıkta olup askerî güçlerinin bulunduğunu hatırlatmıştır. Kelam ulemasının görüşüne göre Şia'nın İslam dairesi içerisinde addedildiğini belirten müellif, Şia'nın da kendi içerisinde firkalara ayrıldığını, her bir firkanın sahabeye sövmeyi meşrulaştırmadığını ifade etmiştir. Kendi hocalarından Atiyye el-Mekkî'den ${ }^{28}$ aktardığına göre, adı geçen hocasının Haricîler içerisinde Allah'a yakınlaşmak için günde Ali'ye bin defa lanet edenleri gördüğü vaki olmuştur. ${ }^{29} \mathrm{Bu}$ şekilde bir karşılaştırmayla sadece Şiîlerin değil, birçok Müslüman güruhun tekfir edilmesi gibi bir tehlikeyle karşı karşıya kalınacağının altını çizmek istemiştir.

Bu çerçevede Özbeklerin Şiîlere karşı gerçekleştirdikleri katliamları, kadınlarına tecavüz edilmesinin din ile bağdaşmadığını savunan el-Kârî, bu fiillerin zahiren kâfirlerin bir Müslümana reva göreceği uygulamalar olduğunu belirtmiştir. Oysa Horasan daru'l-harb değil daru'l-bid'attir. elKârî, yine bir mukayeseye başvurarak Safavîlerin de aynı kötü fiilleri Ehl-i Sünnet'e yaptığını söylemiştir. Oysa her iki devletin uygulamaları da el-

\footnotetext{
25 Nahl (16): 90.

26 el-Kârî, Şemmu'l-Avârız fí Zemmi'r-Revâfiz, 45.

27 el-Kârî, Şemmu'l-Avârız fí Zemmi'r-Revâfiz, 46.

28 Ebû Tâlib Muhammed b. Alî b. Atıyye el-Mekkî el-Acemî (ö. 386/996) olmalıdır. Bkz., Bilal Saklan, "Ebû Tâlib el-Mekkî”, (İstanbul TDVIA 1994), 10: 239-240. 
Kârî’ye göre çok yanlıştır. Nitekim bazı ulema, içerisinde binlerce kişinin yaşadığı küfür diyarında bir kale fethedildiğinde, buradaki insanlardan biri bile zimmet ehli ise bu insanları öldürmenin dinen caiz olmadığını belirtmiştir. Bu çerçevede müellifimiz her iki Müslüman grubun yaptıklarını İslam dışı uygulamalar olarak kabul etmiştir. ${ }^{30}$

\subsection{Rafizîler Ancak Zannî Delillerden Hareketle Öldürülebilir}

Bunca delilden sonra el-Kârî, meseleyi öyle bir zemine taşımıştır ki adeta eserin başı ve sonu arasında bir kayma yaşanmıştır. Zira Rafızîlerin öldürülmesine dair her ne kadar kat'î delil bulunmasa da zannî delillerin mevcut olduğunu ve bununla amel edilebileceğini savunmuştur. Bu noktadan hareketle ilk yaptığı şey fetih suresinin 29. ayetini tefsir etmek olmuş ve ayeti dört halife için işaretler bulunduğundan hareketle onlar lehine tevil etmiştir. Sonrasında ise içerisinde Rafızî ibaresinin yer aldığı bir takım âhâd hadislere yer vermiştir. Hatırlanacağ 1 üzere, akait meselelerinin âhâd hadislere dayalı bina edilemeyeceğini kat'î bir şekilde savunan el-Kârî, meseleyi akait boyutundan çıkartmış, bu sahada zannî delillerin kullanılabileceğini savunmuştur. ${ }^{31}$

Nitekim mevzuu sahabelerin efdaliyeti meselesine bağlayarak, efdaliyetin akidevî bir mesele olmadığını söylemiştir. Binaen aleyh, bu hususta İslam içerisinde birçok farklı görüş bulunmasının, aslında meselenin yakinî bir boyut taşımadığına delil olarak sunmuştur. Ayrıca ona göre bu bahiste öne sürülen rivayetlerin mahiyeti meselenin yakiniyat içerisinde değerlendirilmesine metodik olarak engel teşkil etmiştir. el-Kârî, üstelik böyle bir mevzuun takva ile ilişkili olduğunu ve bunun tespitinin insanlar tarafindan mümkün olmadığını dile getirmiştir. ${ }^{32}$

el-Kârî, bu açıklama akabinde tekrar Rafizîleri yeren hadislere yer vermeye başlamıştır. Daha sonra her ne kadar bu hadislerin senetlerinin zayıf olduğunu kabul etmişse de her bir hadisin diğerini destekleyip hasen derecesine ulaştı̆̆ını belirterek, Rafızîlere yönelik pratiklerin nasıl olması gerektiğine dair vereceği hükmüne zemin hazırlamıştır. Kitabın ilk bölümü diyebileceğimiz kısmındaki ifadeler ve argümanlarla çelişmemek için,

30 el-Kârî, Şemmu'l-Avârız fí Zemmi'r-Revâfiz, 50-52.

31 el-Kârî, Şemmu'l-Avârız fí Zemmi'r-Revâfiz, 52-62.

32 el-Kârî, Şemmu'l-Avârız fí Zemmi'r-Revâfiz, 63-66. 
sahabeye gerek Haricîlerden ve gerekse Rafizîlerden sövenlerin öldürülebileceğini dile getirmiş, ancak bunun şeriatın kat'î delilleri gereğince değil, füru sayılan siyasetin örfüne göre yapılabileceğini savunmuştur. Üstelik bu şekilde Hanefi mezhebince Rafizîlerle savaşmanın ve onları öldürmenin delil getirilemeyeceğini iddia edenleri püskürttüğünü savunmuştur. Ancak bunun, Rafızîlerin kadın ve çocuklarına el sürülmeyeceği, esir edilen veya itaat altına alınanların öldürülemeyeceği kaydıyla yapılabileceğinin altını çizmiştir. ${ }^{33}$

el-Kârî'nin Şemmu'l-Avârı fí Zemmi' r-Revâfiz adlı eseri bu kısımdan sonra Rafızîler ve onların öldürülmesine ilişkin meselelerden uzak kalmıştır. Müellifimiz, eserinde haset için özel bir başlık açarak kendisini kıskananlara bir mesaj göndermiş gibidir. Zira eserin dibacesinde ilimden anlamayan insanların kendi meclisinden el etek çektiğini belirtmiştir. Burada o kadar açık olamasa da bu insanları kınamaya devam ettiğini düşünmek mümkün görünmektedir. ${ }^{34}$ Daha sonra fesat zamanında uzlette kalmanın yapılacak en iyi iş olduğunu belirten el-Kârî, geçmiş insanlara sövmenin kişiyi adaletten düşürüp, mahkemede şehadetinin kabul edilmesine engel teşkil ettiğine dair fikıh kitaplarından alıntılar yapmıştır. ${ }^{35}$ Akabinde eserde Kemalpaşazade'nin yapmış olduğu ulemanın yedi dereceli tasnifi hakkında bilgi verilmiş; kadılar, müftüler ve hüküm verirken uymaları gereken bazı kurallar vb. konulara değinmiştir. ${ }^{36}$ Eser bu bilgilerle son bulmuştur.

\section{Ali el-Kârî'nin Sülâletu'r-Risâle fî Zemmir-Revâfiz min Ehli'd- Delâle Adlı Eseri}

Ali el-Kârî'nin, yukarıda değindiğimiz Şemmu'l-Avârız fi Zemmi'r-Revâfiz eseri haricinde, Râfizî reddiyeleri olarak isimlendirebileceğimiz türe eklenebilecek Selâletü'r-Risâle fì Zemmir-Revâfiz min Ehli'd-Delâle ${ }^{37}$ adli bir başka telifi daha bulunmaktadır. Aslında bu esere Şemmu'l-Avârız'ın telhisi denilebilir. el-Kârî her iki eserinde Selâletü' $r$-Risâle'nin bir telhis olduğundan söz etmemişse de muhtevanın geneli, ele alınışı ve örneklen-

\footnotetext{
33 el-Kârî, Şemmu'l-Avârız fì Zemmi'r-Revâfiz, 66-68.

34 el-Kârî, Şemmu'l-Avârız fí Zemmi'r-Revâfiz, 88-93.

35 el-Kârî, Şemmu'l-Avârız fí Zemmi'r-Revâfiz, 93-111.

36 el-Kârî, Şemmu'l-Avârız fí Zemmi'r-Revâfiz, 111-139.

37 Eser matbu olarak yayımlanmıştır, bkz., Ali b. Sultan el-Karî, Sülâletü'r-Risâle fî Zemmir-Revâfiz min Ehli'd-Delâle, (Amman: Daru Ammar, 1410/1990).
} 
dirilmesinden durum çok açıkça bu yönde bir yorum yapmamıza elvermektedir. Eserlerde telif tarihleri belirtilmediğinden Selâletü'r-Risâle'nin Şemmu'l-Avârı'ın ilk hali olduğunu, el-Kârî'nin Selâletü 'r-Risâle'yi genişlettiğini düşünmek de mümkündür.

O halde burada sorulması gereken müellifimizin neden böyle bir telhise ihtiyaç duyduğu, bir başka tabirle eserini özetleyerek neden yeniden ele aldığıdır. Bundan muradı muhtemelen eserin daha kolay okunmasını ve yaygınlaşmasını sağlamak olmalıdır. Zira telhis, dönemin şartları düşünüldüğünde, hem istinsahı hızlandırıyor, hem bu sayede tedavüle girip daha geniş bir kitleye ulaşmasını kolaylaştırıyordu. Hacimli bir esere mukabil iki varağ geçmeyen bir eserin istinsahı elbette daha ucuzdu; dolayısıyla toplumun çeşitli katmanlarına ulaşma olanağ 1 artmaktaydı. Söz konusu durum müellif açısından düşünüldüğünde bazı avantajları bulunmaktaydı. Zira hacimli bir eserin müellifin kendisi tarafindan telhis edilmesi, işaret edilen tedavüle girme bağlamında kolaylıklar sağlamaktaydı. Böylece müellifin, görüşlerinin hacimli bir eserin muhtevasının yaygınlaşmasının oranından daha geniş bir okuyucu kitlesine ulaşabildiğini düşünebiliriz.

Ancak Selâletü'r-Risâle'nin Şemmu'l-Avârı'ı'n ilk hali olduğunu kabul edecek olursak bu cevabın işlevsel bir niteliği kalmayacaktır. Böyle bir durum söz konusuysa, bazı gerekçelerle müellifin eserini genişletme ihtiyacı duyduğu düşünülebilir. Belki esere daha kapsamlı bir nitelik kazandırılmasının başlıca nedeni müellifin Şemmu'l-Avârız'da belirttiği gibi, Rafızîler hakkında görüşlerinden dolayı kendisine getirilen eleştiriler ve akabinde bunun bir neticesi olarak sohbet meclislerinin boykot edilmesidir. el-Kârî'nin söz konusu ulemayı eleştirmesinden ve meseleyi anlayamadıklarından hareketle boykotçular diye tanımlayabileceğimiz zümrenin ilmiye sınıfından olduğunu düşünebiliriz. Binaen aleyh müellifimizin Sülâletü' r-Risâle'yi daha kapsamlı bir esere dönüştürüp, kendi delillerini detaylandırdığı akla gelmektedir.

Yukarıda Ali el-Kârî'nin Şemmu'l-Avârız unvanlı eserini irdeledikten bu açıklamalardan sonra, Selâletü' $r$-Risâle isimli risalesinin evvela tercümesini burada zikredip akabinde diğer eserle fark ve benzerliklerini irdelemeye çalışacağız. Bundan önce, mevzuya bahis risalenin muhtelif bazı yazma nüshalarının künyelerinin verilmesi yerinde olacaktır. 
1. 000298 Süleymaniye Damad İbrahim, Arapça, Sülâletü'r-Risâle fi Zemmi'r-Revâfid min Ehli'd-Dalâle. / Nureddin Ali b. Sultan Muhammed el-Herevi Ali el-Kari. -- [y.y.] : Yazma, [t.y.] 280-282 vr.

2. 003524 Süleymaniye Esad Efendi, Arapça, Sülâletü'r-Risâle fi Zemmi'r-Revâfıd min Ehli'd-Dalâle. / Nureddin Ali b. Sultan Muhammed el-Herevi Ali el-Kari. -- [y.y.] : Yazma, [t.y.] 88-90 vr.

3. 005332 Süleymaniye Fatih, Arapça, Sülâletü'r-Risâle fi Zemmi'rRavâfıd min Ehli'd-Dalâle. / Nureddin Ali b. Sultan Muhammed elHerevi Ali el-Kari. -- [y.y.] : Yazma, [t.y.] 97-99 vr.

4. 000251 Süleymaniye H. Hüsnü Paşa Arapça, Sülâletü'r-Risâle fi Zemmi'r-Ravâfıd min Ehli'd-Dalâle, [y.y.] : Yazma, [t.y.] 192-194 vr.

5. 001439 Süleymaniye Hamidiye, Arapça, Sülâletü'r-Risâle fi Zemmi'rRevâfid min Ehli'd-Dalâle. [y.y.] : Yazma, [t.y.] 244-246 vr.

6. 001201 Süleymaniye Reisülküttab, Arapça, Sülâletü'r-Risâle fi Zemmi'r-Revâfid min Ehli'd-Dalâle. [y.y.] : Yazma, [t.y.] 161-162 vr.

7. 001146 Süleymaniye, Reisülküttab, Arapça, Sülâletü'r-Risâle fi Zemmi'l-Revâfid min Ehli'd-Dalâle, [y.y.] : Yazma, [t.y.] 251-252 vr.

8. 004978 Nurosmaniye, Arapça, Sülâletü'r-Risâle fi Zemmi'r-Revâfid min Ehli'd-Dalâle. / Ebü'l-Hasan Nureddin Ali b. Sultan Muhammed Ali el-Kari. -- [y.y.] : Yazma, [t.y.] 1 c. (188-189 vr.)

9. Suud Kraliyet Üniversitesi Yazmalar Bölümü, Arapça, Sülâletü'rRisâle fi Zemmi'r-Revâfıd min Ehli'd-Dalâle. /Ali b. Sultan Muhammed Ali el-Kari. -- [y.y.] : Yazma, , 1486/1.

Bizim burada esas aldığımız nüsha Nurosmaniye nüshasıdır. Risale iki varak, üç sahifeden müteşekkil olup eserin ilk sahifesinde başlı̆̆ kırmızı mürekkeple Sülâletu'r-Risâle fì Zemmi'r-Ravâfiz min Ehli'd-Dalâle şeklinde yazılmıştır. İlk iki sahife eserle ilgilidir ve her biri 27 satırı ihtiva etmektedir. Üçüncü sahifenin ise 17 satırı eserden olup sonrasında müellifinin bir başka eseri olan es-Sanî' 'atu'ş-Şerîfe fî Tahkîki'l-Buk'ati'ş-Şerîfe başlamaktadır. Eser ham okunaklı bir yazıyla yazılmış hem de maddi bir yıpranmaya uğramadığından tam olarak tercüme edilebilmiştir. Aşağıda Arapça telif edilmiş bu eserin tercümesi yazma sahifeleri gösterilerek verilmiş, sonrasında değerlendirilmiştir. 


\section{Sülâletu'r-Risâle fî̀ Zemmi'r-Ravâfız min Ehli'd-Dalâle Adlı Eserin Tercümesi}

\section{Sahife: $188 b$}

\section{Sülâletu'r-Risâle fî Zemmi 'r-Ravâfiz min Ehli'd-Dalâle}

Rahman ve Rahim olan Allah'ın Adryla

Tüm övgüler tek olan Allah'a mahsustur. O'nu elçisine ve akabinde elçinin ashabina, taraftar ve askerlerine selam olsun. Ba'dehu: Bu (eser) Selâletü'r-Risâle fí Zemmi'r-Rev'afiz min Ehli'd-Delâle (adlı risale)dir. Içerisinde nezdimde sabit olan bazı deliller bulunmaktadır. Öncelikle (şunu) bil ki; her şeyden münezzeh şanı yüce Allah (Kur'ân'da) sahabe hakkinda "Allah onlardan razıdır, onlar da Allah tan razıdırlar"38 buyurmuştur. (Hz. Peygamber de) "kim ashabıma söverse Allah'ın, tüm meleklerinin ve insanların laneti onun üzerine olsun; her kim onların (hukukunu) muhafaza ederse ben de onu klyamet gününde muhafaza ederim." buyurmuştur. Bu (hadis)i İbni Asakir, Cabir'den; Taberanî ise İbni Abbas 'tan rivayet etmiştir. Insanlardan her hangi birine sövmek yasaklanmış iken Allah'ın razı olduğu kişilere (sövmek yasak olmaz mı?) Ulemanın büyükleri Yezid, Haccac ve onlar gibileri hakkinda şekavet ehline lanet etmeyi men etmiştir. Bunun yanı sıra "şeytana sövmeyin onun şerrinden Allah'a slğının” şeklinde hadis varit olmuştur. İkinci olarak (bil ki;) Şeyhayn' $e^{39}$ sövmek Kur'ân, sünnet, icma ve klyas gereğince küfrü gerektirmez. Kitap (Kur'ân)daki (delile gelince) nitekim Allahu Teâla buyurmuştur ki "Allah kendisine ortak koşmayı affetmez. Bundan başka her şeyi, istediğine bağışlar." ${ }^{40}$ Hanbeli ulemanın büyüklerinden olan İbni Teymiye 'Ashablma sövmek bağışlanmayacak bir günahtır' hadisi peygambere yalan (isnat)tır. Nitekim Allahu Teâlâ "Allah kendisine ortak koşmayı affetmez. Bundan başka her şeyi, istediğine bağışlar” buyurmuş̧ur.' demektedir. (Sövücünün küfrü mevzuunun küfrü gerektirmediğinin) sünnetteki (delili) ise, neredeyse mütevatir kabul olabilecek bir hadiste geçmektedir. "Müs-

\footnotetext{
38 Beyyine (98): 8. Ayetin tamamının meali şu şekildedir: "Rableri katındaki mükâfatları, içlerinde ebedî olarak kalacakları, altlarında nehirler akan ikamet Cennetleridir. Allah onlardan razıdır, onlar da Allah'tan razıdırlar. İşte bu mükâfat, Rabbinin büyüklüğüne karşı ürperenler içindir."

39 İki şeyh anlamında Hz. Ebu Bekir ve Hz. Ömer için kullanılmaktadır.

40 Nisâ (4): 48
} 
lüman birine küfür etmek fisk, onu öldürmek ise küfürdür/kâfirliktir.” Bu (hadisi) Buhari ve Müslim ve başkalart rivayet etmiştir. Bu (bağlamda) Taberanî'nin Hz. Ali'den -Allah ondan razı olsun- rivayeti bulunmaktadır. "Her kim peygamberlere söverse öldürünüz, ashabıma söveniyse dövünüz." Ayn şekilde Kadı Iyaz da kendi senediyle bu hadisi rivayet etmiştir. Hâkim 'in ve Beyhakî Sünen 'inde de sahih kabul ettiği Ebû Davud'un bir başka rivayetinde Ebû Berze el-Eslemî'den şu şekilde rivayet etmiştir: "Ebû Berze el-Eslemî dedi ki: Bir gün Ebû Bekir es-Siddık-Allah ondan

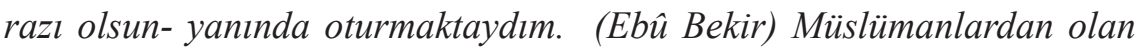
bir adama öfkelendi." Nesaî ise şöyle rivayet etmiştir: "Ebû Bekir'in yanına gittiğimde bir adam ona ă̆ır sözler söylemekteydi; o da ona cevap verdi. Ebû Berze dedi ki: Ben de ey Allah resulünün halifesi! Sana sövmesi nedeniyle onun boynunu vurmam için bana izin ver." SSifa adl eserde bir grup ulemadan şu aktarılmıştır: Bir adam Ebû Bekir'e sövmüş, (Ebû Berze'nin o adamı öldürmek için izin istemesi ardından Ebû Bekir ona cevaben) otur. Bu (isteğin) ancak Resulullah'a (sövülmesi) için (geçerlidir, demiştir.) Yani diğer peygamber kardeşleri gibidir; (Onlar için geçerli olan hüküm ona sövülmesi durumunda da geçerlidir.) Kadı (İyaz) demiştir ki, "bu hükmünde kimse ona (Ebû Bekir'e) muhalefet etmemiştir. Bu nedenle Ömer b. Abdülaziz, Ömer'e -Allah ondan razı olsun- söven birinin öldürülmesi hususunda kendisiyle istişare için mektup yazan Kufe amiline yazdiğg (emirnamede, bu hususta) Resulullah'a sövmeyen birinin insanlardan birine sövmesi nedeniyle öldürülemeyeceğini bildirdi. Resulullah'a söveninse kanı helaldir."

\section{Sahife: 188a}

Yani icma ile bu durum sabittir. Zira (bu eylemiyle) kati bir şekilde dinden çıkmaktadır. (Kadı İyaz)'in söylediğini ulemanın Resulullah'in (hadislerinden) tahriç ettikleri de tasrih etmektedir. Buna göre Allah'tan başka ilah olmadiğına ve Muhammed'in O'nun elçisi olduğuna inanan birinin kanı dökülemez. Şu üç kişi hariç; ihtiyar zinakar, kısasa tabi olan kişi, mürtet olup toplumdan ayrllan. Ícmada (bu husustaki delile gelince), ashaptan ve de tabiinden Şeyhayn'e söven kişinin küfrüne ve söven kişinin öldürüleceğine dair herhangi bir şey varit olmamıştır. Eimme-yi selâse ${ }^{41}$ bu durumdaki

41 Hanefi Mezhebine dâir meselelerin geçtiği kitaplarda Eimme-i Selâse'den maksad; İmâm-1 A'zam ile iki talebesi olan İmâm-1 Muhammed ve İmâm-1 Ebu Yusuf'dur. 


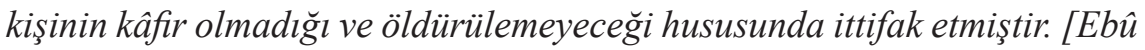
Hanife ve ${ }^{42}$ Eb̂ิ Yusuf'un sahih görüşüne göre Hattâbîler ${ }^{43}$ hariç, Haricî ve Rafizî ehlinin şehadeti geçerlidir. Ebû Yusuf'tan (nakledilen bir görüşe göre) sahabeden teberri eden kimsenin şehadeti makbul, onlara sebbeden kişinin ise adaleti batıldır. Metin yazarları ve onların şârihleri sahabeye sebbettiği ortaya çıkan kişinin fiskl, (sebbettiğini) saklayanın aksine ortaya çıkmış olduğundan, şehadeti kabul edilmez. Mecma'u'l-Ma 'nâ'nın şerhinde selefe açıkça sebbedenin fiskı ortaya çıktığından icma ile şehadetinin kabul edilmeyeceği (belirtilmiştir); (sebbettiğini) gizleyen kişinin bu hali gizli kaldığından o bu hükmün dışındadır. Hülâsa'da zikredilen şeyheyne sebbedenin küfrüne dair (görüs) ise yukarıda aktarllan cumhurun görüşüne ters düşen şaz bir rivayettir. Bu hususta imamlarımızdan ne makbul bir nakil, ne bir nakledilmiş delillendirme ve ne de mevzunun şeyheyne münhasir olduğunu bildiren bir makul bir görüş bulunmaktadır. Ahmed ve Hakim 'in Müstedrek'inde Ümmü Seleme'den rivayet edilen "Ali'ye sebbeden bana sebbetmiştir ve bana sebbeden de Allah'a sebbetmiştir" şeklinde rivayet edilen hadis de bulunmaktadır. ${ }^{44}$ Ayrıca Mecmû'u'n-Nevâzil'de "Eğer biri şeyheyne sebbettiğinden veya lanet ettiğinden dolayı öldürülürse onun için kısas gerekmez, çünkü o kâfirdir ve söyledikleri peygamber sallallahu aleyhi ve selleme gitmektedir" (şeklindeki görüş ise) anlaşılacağı üzere sözün sahibinden uzak, nadir ve yukarlda geçen birçok rivayete aykırt; metinleri ve onların meşhur şerhlerini nakzeden bir rivayettir. Evet, zikrettiği talil, medhûl-i gayr-i ma'kûl (مدخول غير selmakla birlikte, Nebi'inin ashabından olduklarl için ikisine sebbedilirse (bu sebebbetme eylemi) küfür (sebebi)dir. Aynı şekilde Ali, Ayşe gibi ikisi dişındakilere ve benzerlerine de (sebbetmek küfürdür). Hatta icmâen bir Müslümana İslamiyet'inden dolayı sebbetme, tıpkı kasten onu öldürmek küfür olduğu gibi (bu da) küfürdür. Kıyas açısından ise, Ebû Hanife 'nin Fıkhu'l-Ekber'de zikrettiği usul tüm mütekellimlerinkine muvafiktır. (O da şudur): Bir günahtan dolayı kıble ehlinden kimse tekfir edilemez. Bu (Rafizîlerin) kıble ehli olduklarında şüphe yoktur. Enes'ten merfu şekilde varid olduğuna göre, "ü̧̧ şey imanın aslındandır; Lâ ilâhe illallâh diyen kişin(in canına kastetmekten) el çek-

42 Bazı nüshalarda bu şekildedir.

43 Ebü'l-Hattâb el-Esedî (ö. 138/755 [?]) tarafından kurulan aşırı Şiî firkası. Bkz., Hasan Onat, "Hattabiyye", (İstanbul TDVIA 1997), 14: 492-493.

44 el-Kari’nin u hadisi zikretmesinin nedeni durumun Şeyheyne münhasır olmadığını göstermektir. 
mek, günah eyleminden dolayı onu tekfir etmemek, onu İslam (dairesinden) çıkarmamak." (Bu) hadisle amel ederek (biz böyle birini) tekfir etmez ve İslam'dan çıkarmayız. Birinci fikrada Haricîlere ve Rafizîlere, ikinci firkada ise Mu 'tezile'ye cevap verildi. Furû'a göreyse, Ehlisünnet velcemaat'in ittifak ettiğine göre

\section{Sahife 189b}

Bir Müslüman’ı öldüren (Müslüman kişi) kâfir olmaz, buna göre evla olan sebbedenin de küfrüne hükmedilmemesidir. (Nitekim Ehlisünnet ulemasi) Osman 'in, Ali'nin ve Hüseyin 'in katillerinin küfre düşmedikleri hususunda icmâ etmistir. (Öyle ki öldürülenler), aralarında arınmıs seyyidler ve müttaki âlimler bulunan peygamber sahabesi ve tabiinden yüz yirmi bin kişiyi öldüren Haccac hakkında Ehlisünnet (uleması)ndan hiç kimse onun küfrünü dile getirmemiştir. İtimat edilmesi (gereken görüss) Allâme Teftâzânî'nin el-Mu'teked'te zikrettiği gibi, sahabeye sebbetmenin fisk ve bidat olduğudur. Onun bu görüşünü Sühreverdî'nin hatırlatması desteklemektedir: Ali ve Muaviye düşmanlık üzere savaştaydı. Iki grup birbirine sebbetmekteydi. Onlardan biri diğerinin küfrüne hükmetmemiştir. Günahları kendi boyunlarınadır, onardan gördüğünüz cahillere ve sebbedenlere bakıp hiç kimseyi tekfir etmeyin. Mültekât'ta ${ }^{45}$ belirtildiği üzere; Ebû Hanife, Eb̂̂ Yusuf ve Züfer demişlerdir ki, birinin bizlerin görüşlerimizi nereden söylediğimizi bilmeden onlar ile fetva vermesi caiz değildir. Mukallidin müçtehidin görüşüyle (bu şekilde bilgisizce) delilini bilmeden fetva vermesi caiz değilken, kendi görüşüyle ve delil getirmeksizin fetva vermesi nasil olabilir. Üstelik kitap ve sünnette mevcut deliller verdiği fetvaya muarı durumdadir. İbni Asakir'in Ali'den rivayet ettiğine göre, her kim ilmi olmaksızın bilgisizce fetva verirse sema ve arz meleklerinin laneti onun üzerine olur. Aynı şekilde ulemamız demistir ki, bir kimsenin küfrüne (delil olarak) doksan dokuz rivayet mevcutsa ve bir rivayet de onun Islamiyet'ine dair (delil teşkil ediyorsa) müftünün bu bir rivayete göre amel etmesi gerekmektedir. Zira müminin hayatta kalıp kurtulmasina yönelik hatası, onun (ölümüne sebep olacak) had ve kisas hatasindan daha hayırlıdır. Noksanlıklardan

45 İmam Nasirıddin Ebi'l-Kasım Muhammed b. Yusuf el-Huseynî es-Semerkandî, elMultekat fi Fetâveye'l-Hanefiyye, Tahkik: Mahmud Nassar-Seyyid Yusuf Ahmed, (Beyrut: Darul Kutubul İlmiyye, 2000/1420). 
münezzeh olan Allah bizleri zellelerden korusun ve ecelimizin son buldu$\breve{g}$ anda sonumuzu güzel kilsin. Muhammed'e o'nun ehlibeyt ve ashabina Allah'in salatı olsun.

Eserde ilk olarak sahabeye sövmenin yanlış olduğuna değinerek bir giriş yapılmıştır. Benzer bir giriş Şemmu 'l-Avârız'da da bulunmaktadır. el-Kârî, sonrasında sahabeye sövmenin kişiyi küfre sokmayacağını belirtmiştir. Akabinde Şemmu'l-Avârız'da olduğu gibi, Kur'ân ayetlerinden ve senetlerinin sahih olduğunu belirttiği hadislerle iddiasını kanıtlamaya girişmiştir. $\mathrm{Bu}$ delilleri icmadan getirdiği delillerle de pekiştirmeye çalışmıştır. Mevzuun bağlamını ulemanın görüşlerine yer vererek ayet ve hadis metinlerinin dışına taşımış, tezinin cumhurun görüşünden başka bir görüş olmad1ğın belirtmiştir. Buna göre Şeyhayn'e sebbedenin küfrüne dair ileri sürülen hadis ve görüşler, cumhurun çıkarımlarıyla bağdaşmadığ 1 için kabul edilemez diyen müellif, bu görüşe ters düşen rivayetlerin şaz rivayet olduğuna hükmetmiştir.

\section{Sonuç}

el-Kârî her iki eserinde Sülâletü 'r-Risâle'nin bir telhis olduğundan söz etmemişse de muhtevanın geneli, ele alınışı ve örneklendirilmesinden durum bu yönde bir yorum yapmamıza elvermektedir. Eserlerde telif tarihleri belirtilmediğinden Sülâletü'r-Risâle'nin Şemmu'l-Avârız'in ilk hali olduğunu, el-Kârî'nin Selâletü'r-Risâle'yi genişlettiğini düşünmek de mümkündür. Bunun yanı sıra Şemmu'l-Avârız'1 yazdıktan sonra mevzuya bahis konu hakkındaki görüşlerinin daha çok insan tarafından bilinmesi için Selâletü'r-Risâle' yi kaleme almış olabilir.

el-Kârî makaleye konu edilen her iki eserinde Rafizî olarak tanımladı̆̆ı Safavî Şiîlerinin tekfir edilip edilemeyeceğini fikıh metodolojisi açısından değerlendirmiş̧ir. Her iki telifindeki görüşü Rafızillerin ehli kıble sayıld1$\breve{g} 1$, fikıh kaynaklarından hareketle İslam dairesi içerisinde yer alan ehl-i kıbleden sayıldıkları ve tekfir edilemeyecekleri, kanlarının Müslümanlar tarafindan dökülemeyeceği şeklindedir. Ancak Şemmu'l-Avârız'da zanni delillerle Rafızilerin katledilebileceğini ifade etmiştir. $\mathrm{Bu}$ minvalde elKârî zanni delilleri adı geçen eserinde zikretmiş ve Rafızîlerden sahabeye sövenlerin öldürülebileceğini dile getirmiştir. Bu görüşü beyan ederken bunun şeriatın kat'î delilleri gereğince değil, zannî delilleri gereğince fur- 
ruattan sayılan siyasetin örfüne göre yapılabileceğini savunmuştur. Dolayısıyla Rafizîler tekfir edilmeksizin fikhî metodolojiyle uyumlu hale getirilen siyaset ve örfün kaidelerince öldürülebilmektedir. el-Kârî bu şekilde meseleyi zannî metodolojinin uygulanabilir olduğu fikıh sahasına taşımış, kat'î delillerin cari olduğu akaid dairesinden çıkarmıştır.

Ali el-Kârî Şemmu'l-Avârız'da zannî delillere göre Rafizîlerin öldürülebileceğini söylemekteyse de Sülâletü'r-Risâle' de bu görüşe yer vermemiştir. $\mathrm{Bu}$ çerçevede onun boykot çevresince kendine yapılan mahalle baskısı nedeniyle Sülâletü'r-Risâle' de yer vermediği görüsslere Şemmu'l-Avârız'da yer verdiğini düşündürecek şüphelere sahip olmaktayız. Durum gerçekten böyleyse, Şemmu'l-Avârız'ın sonradan yazıldığı kesinleşmektedir. Ancak bundan daha önemlisi el-Kârî’nin çelişik görüşlerindeki tutarsızlığg nasıl anlamamız gerektiğidir. Selâletü'r-Risâle'de yer vermediği zannî delillere dayanarak Rafızîlerin öldürülebileceğine yönelik görüşü gerçekten kendine ait olarak $\mathrm{m}$ aktarmıştır?

Zira her iki eserin merkezinde yer alan ana tema birinin Müslüman olduğuna hükmedilmişse onun tekfir edilip öldürülemeyeceğidir. Aslında el-Kârî̀nin zannî delilleri, boykotçuların "kat'î delil" olarak sundukları argümanlar ile aynıydı. el-Kârî, onların "kat'î delillerini" eserinde "zannî delile" dönüştürmüş oldu. Bu şekilde belki siyasal ve sosyolojik bazı çekincelerini bertaraf etmiş oldu. Ayrıca icmaın Şia'nın Müslümanlığına hükmettiğini ve bir Müslümanın da öldürülmeyeceğini savunduğu halde, bunu açıkladıktan sonra Şemmu'l-Avârız'da onların öldürülebileceğini savunarak boykotçuların meseleyi ele alışlarını gözden geçirmeleri gerektiğini hatırlatmış olabilir. Binâen aleyh, hiç bir şeyden haberi olmayan kadın, çocuk ve sıradan insanların meselenin dışında tutulmasını istemiştir.

el-Kârî, Şii Safavîler kadar Sünnî Özbeklerin uygulamalarını eleştirmiştir. Muhtemelen daha kapsamlı yazılması hasebiyle müellifin Şemmu'lAvârlz'da yer verdiği otobiyografik içtimaî gözlemler ve deneyimler bu hususta önemli malumatı ihtiva etmektedir. Topraklarına kaçtığı ve orada yaşadığı Osmanlı yönetiminin, Safavî Şiilerinin yurdunu neden daru'lharb ilan ettiği ve icmaa göre Müslüman addedilen kişileri öldürdüğünü görmezden gelip susmasının ardında önem arz eden bir şey vardır.

Kanaatimce el-Kârî ilim meclislerinde dile getirip savunduğu görüşleri Sülâletü'r-Risâle'de derledi. Ancak sonrasında boykotun gerçekleşmesi nedeniyle içinde yaşadığ 1 içtimaî doku ve siyasa, onu yanlış anlayabileceği 
zemine kaymaya başladı. Bu kayma kendisini temize çıkaracak bir girişime sevk etti. Yeni bir eser kaleme alarak Sülâletü'r-Risâle'de savunduğu görüşü daha geniş bir şekilde eserin ilk bölümünde ele aldı ve temellendirdi; ikinci bölümde ise kırıldığını düşündügü fay hatlarını yerine oturtmaya çalıştı.

\section{Kaynakça}

Arıkan, Adem. "Osmanlı Kadısı/Müderrisi Maruf b. Ahmed'in İmâmiye Şîasına Eleştirileri”, Marife 8, no. 3, (Kış 2008): 331-348.

Can, Ali. "Aliyyü'l-Kârî'nin Envâru'l-Kur'ân ve Esrâru'l-Furkân Adl1 Tefsirinde Besmele Yorumu", Dicle Üniversitesi Illahiyat Fakültesi Dergisi 14, no. 2 (2012): 37-66.

Ertürk, Mustafa. "Haber-i Vâhid", Türkiye Diyanet Vakfi İslam Ansiklopedisi, 14: 349-352. İstanbul: TDV Yayınları, 1996.

Karataş, Ahmet. "Aliyyul-Kārinin el-Mulemma' Şerhu'n-Na'ti'l-Murassa' Adlı Arapça Risalesinin Tercüme ve Şerhi”, Tasavvuf Ilmi ve Akademik Araştırma Dergisi 17, no. 37 (2016): 147-197.

el-Kârî, Ali b. Sultan, 004978 Nurosmaniye, Arapça, Sülâletü'r-Risâle $f i$ Zemmi'r-Revâfid min Ehli'd-Dalâle. / Ebü'l-Hasan Nureddin Ali b. Sultan Muhammed Ali el-Kari. -- [y.y.] : Yazma, [t.y.] 1 c. (188-189 vr.)

el-Kârî, Ali b. Sultan, Suud Kraliyet Üniversitesi Yazmalar Bölümü, Arapça, Sülâletü' r-Risâle fi Zemmi'r-Revâfid min Ehli'd-Dalâle. /Ali b. Sultan Muhammed Ali el-Kari. -- [y.y.] : Yazma, 1486/1.

el-Kârî, Ali b. Sultan, Şemmu'l-Avârız fi Zemmi'r-Revâfiz, Kahire: Merkezu Furkan li-Dirasat İslamiyye, 1425/2004.

el-Kârî, Ali b. Sultan, Selâletü'r-Risâle fì Zemmir-Revâfiz min Ehli'dDelâle, Amman: Daru Ammar, 1410/1990.

el-Kârî, Ali b. Sultan, Hâmişi Nesîmu'r-Riyâz fì Şerhi 'ş-Şifâu'l-Kâdî Iyâz ve bi-Hâmişihî Şerhu'ş-Şifâ, Beyrut: Darulkutubul Arabi, 1327.

Kohlberg, Etan. "İmâmiyye Şiası Geleneğinde "Râfizî” Terimi”" çev. Halil İbrahim Bulut, Kelam Araştırmaları 2, no. 2 (2004): 117-124.

Onat, Hasan, "Hattabiyye", Türkiye Diyanet Vakfi İslam Ansiklopedisi, 16: 492-493. İstanbul: TDV Yayınları, 1997. 
Öz, Mustafa, "Rafiziler", Türkiye Diyanet Vakfi İslam Ansiklopedisi, 34: 396-397. İstanbul: TDV Yayınları, 2007.

Özel, Ahmet, “Ali el-Kari”, Türkiye Diyanet Vakfi İslam Ansiklopedisi, 2 : 403-405.İstanbul: TDV Yayınlar1, 1989.

Saklan, Bilal, "Ebû Tâlib el-Mekkî”, Türkiye Diyanet Vakfi İslam Ansiklopedisi, 10: 239-240. İstanbul: TDV Yayınları, 1994.

es-Salimî, Ebu'ş-Şekûr, et-Temhîd fỉ Beyâni 't-Tevhîd, (Tahkik: Ömer Türkmen), İstanbul: Diyanet Vakfı Yayınları, 2017.

et-Teftâzânî, Sadeddin Mesud b. Ömer, Şerhu'l-Akâidi'n-Nesefiyye, (Tahkik: Ali Kemal), Bayrut: Daru İhyaut Turasil Arabi, 1436/2014.

Yavuz, Yusuf Şevki. "Haber-i Vâhid/Kelam", Türkiye Diyanet Vakfi İslam Ansiklopedisi. 14: 352-355, İstanbul: TDV Yayınları, 1996. 
Ek-1: Nurosmaniye, Arapça, Sülâletü'r-Risâle fi Zemmi'r-Revâfıd min Ehli'd-Dalâle. / Ebü'l-Hasan Nureddin Ali b. Sultan Muhammed Ali elKari. -- [y.y.] : Yazma, [t.y.] 1 c. (188-189 vr.) Demirbaş Numarası:004978.

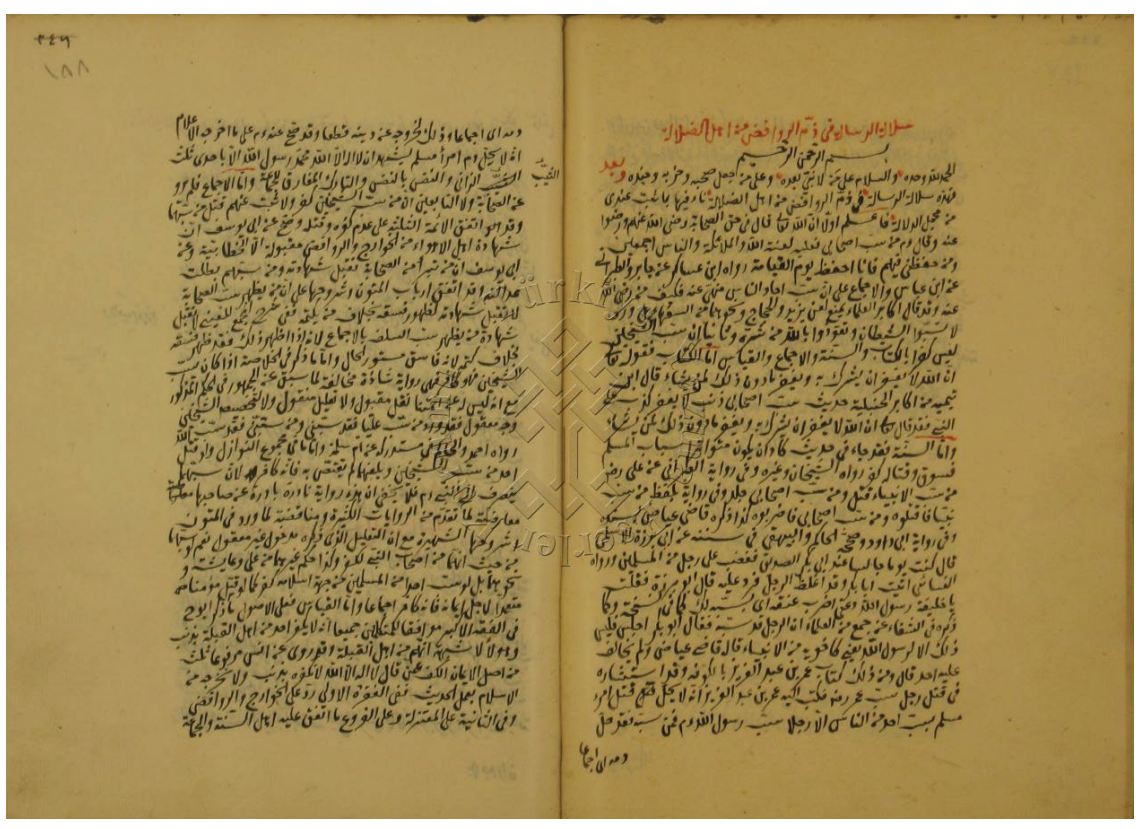

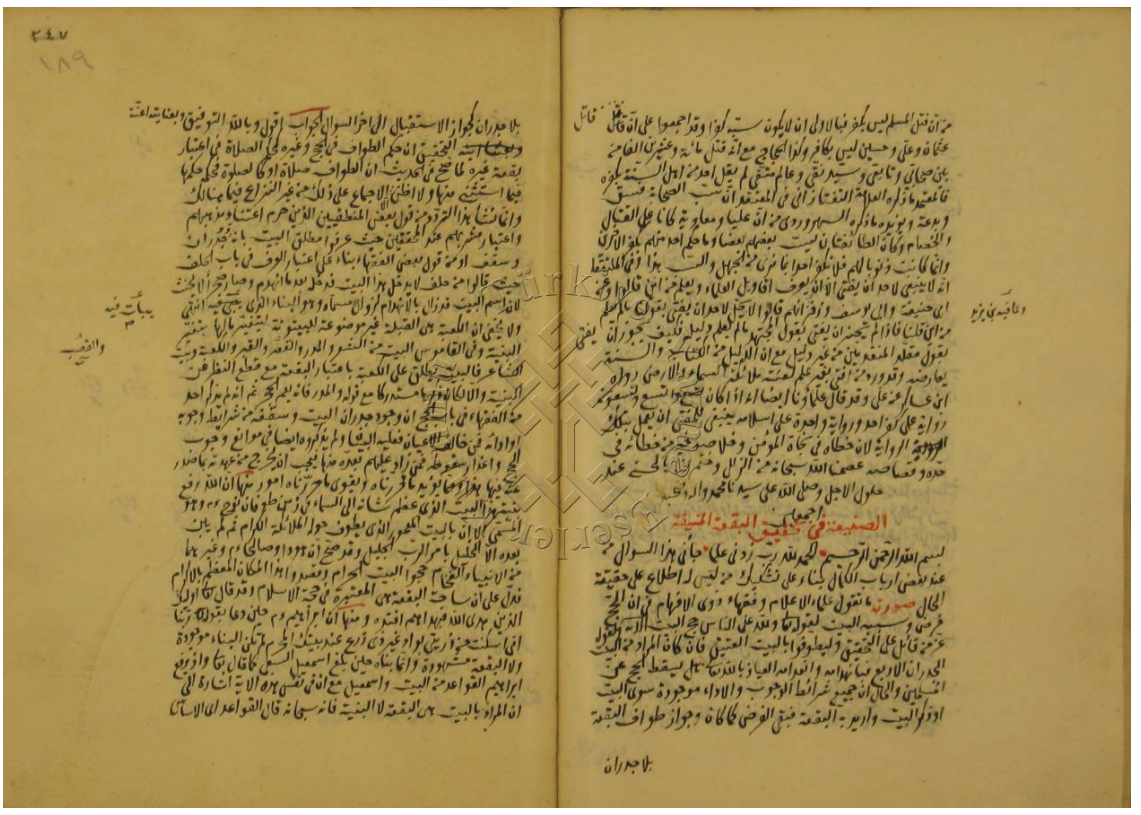


Ek-2: Suud Kraliyet Üniversitesi Yazmalar Bölümü, Arapça, Sülâletü'rRisâle fi Zemmi'r-Revâfid min Ehli'd-Dalâle. /Ali b. Sultan Muhammed Ali el-Kari. -- [y.y.] : Yazma, Demirbaş Numarası: 1486/1.

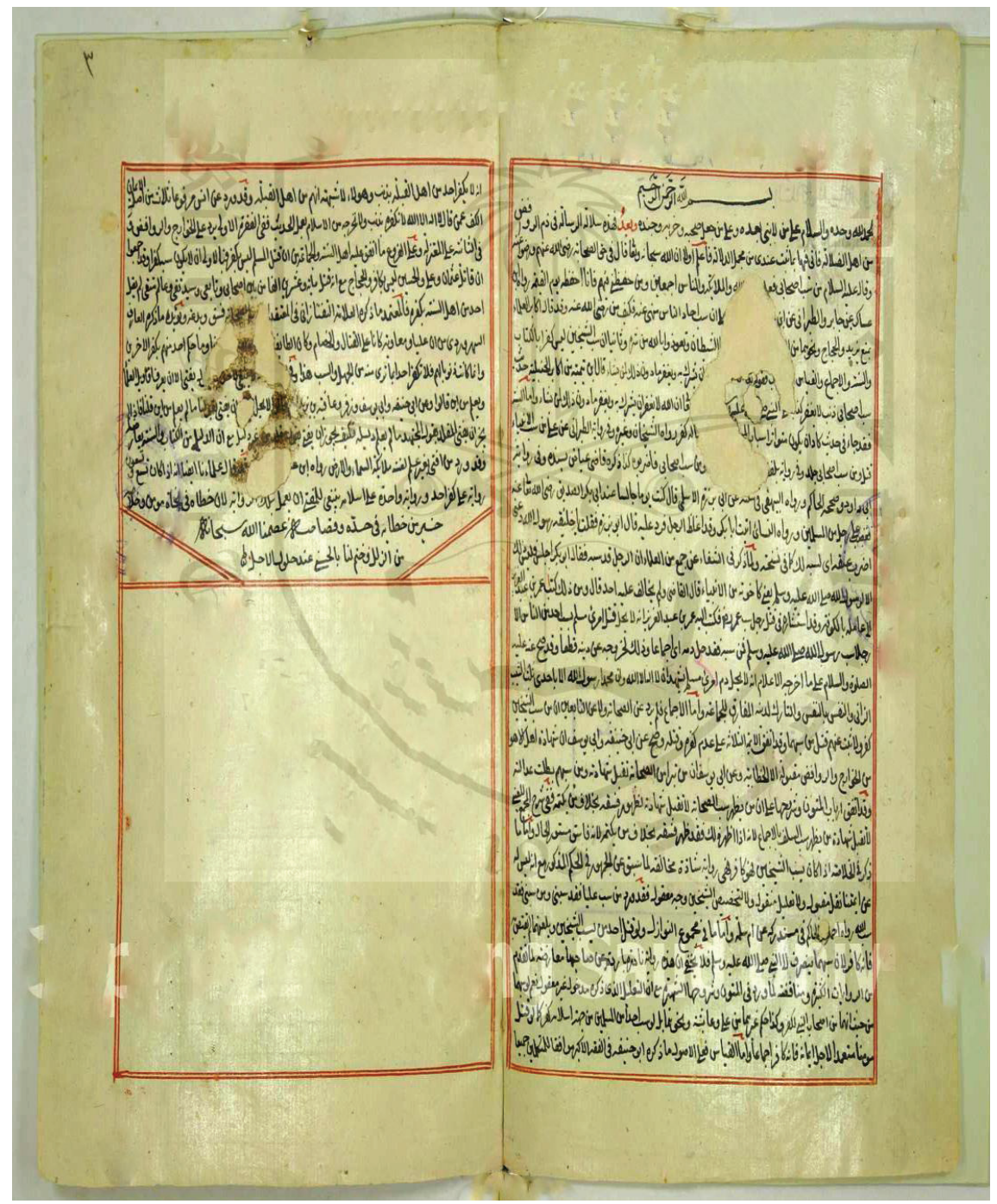

